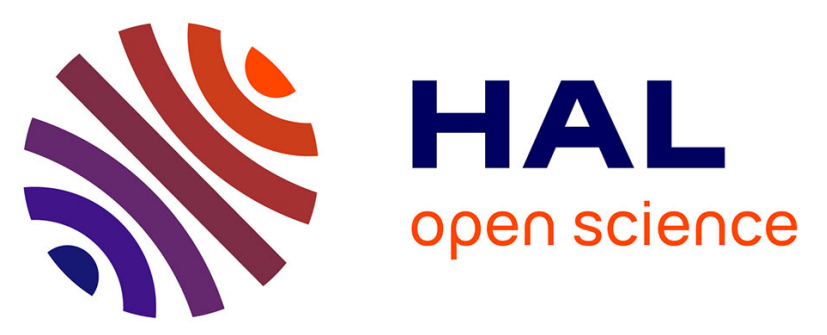

\title{
ENVIRONMENTAL AND TRADE REGIMES: COMPARISON OF HYPERGRAPHS MODELING THE RATIFICATIONS OF UN MULTILATERAL TREATIES
}

Romain Boulet, Ana Flavia Barros-Platiau, Pierre Mazzega

\section{To cite this version:}

Romain Boulet, Ana Flavia Barros-Platiau, Pierre Mazzega. ENVIRONMENTAL AND TRADE REGIMES: COMPARISON OF HYPERGRAPHS MODELING THE RATIFICATIONS OF UN MUltilaterAl TREATIES. Law, Public Policies and Complex Systems: Networks in Action (Springer), 2019. hal-03099822

\section{HAL Id: hal-03099822 https://hal.science/hal-03099822}

Submitted on 4 Jan 2022

HAL is a multi-disciplinary open access archive for the deposit and dissemination of scientific research documents, whether they are published or not. The documents may come from teaching and research institutions in France or abroad, or from public or private research centers.
L'archive ouverte pluridisciplinaire HAL, est destinée au dépôt et à la diffusion de documents scientifiques de niveau recherche, publiés ou non, émanant des établissements d'enseignement et de recherche français ou étrangers, des laboratoires publics ou privés. 


\title{
CHAPTER 11. ENVIRONMENTAL AND TRADE REGIMES: COMPARISON OF HYPERGRAPHS MODELING THE RATIFICATIONS OF UN MULTILATERAL TREATIES
}

\section{Romain Boulet, Ana Flavia Barros-Platiau and Pierre Mazzega}

\author{
R. Boulet (corresponding author)
}

University of Lyon, Jean Moulin, iaelyon, Magellan Research Center, Lyon, France

e-mail: romain.boulet@univ-lyon3.fr

\author{
A. F. Barros-Platiau \\ IREL, Institute of International Relations, University of Brasilia, Brasilia DF, Brazil \\ e-mail: anabarros@unb.br \\ P. Mazzega \\ UMR5563 GET Geosciences Environment Toulouse, CNRS / University of Toulouse, France; \\ Affiliate Researcher SCELG Strathclyde Centre for Environmental Law \& Governance, University of \\ Strathclyde, Glasgow, Scotland \\ e-mail: pierre.mazzegaciamp@get.omp.eu
}

\begin{abstract}
In analyzing the ratifications of Multilateral Environmental Agreements (MEAs) and United Nations-based trade agreements, this study pursues two goals: first, to provide evidence of the limitations of the role played by the United Nations in promoting sustainable development as a bridge between both regimes, although member states are roughly the same; second, on a methodological side, to contribute to the exploration of the use of hypergraphs to model a dynamic in International Relations, as illustrated by analyzing empirical data easily accessible and available on the web. We use 3550 ratification dates of MEAs (1979-2015) and 834 ratifications of trade agreements (1963-2014) available on the website of the United Nations Treaty Collection. The hypergraph-based analysis of the temporal successions of ratifications highlights informal communities of countries whose contours emerge through this uncoordinated process of ratification. The European countries and more specifically members of the European Union, and their Atlantic allies stand out as having the leadership of the construction of a global environmental order. However, no formally established community of countries emerges from the chronology of ratification of the United Nations trade agreements. In this particular UN context, none of the contemporary trade powers is even central to this dynamic. Indeed, most trade negotiations take place outside the United Nations arena, particularly in the framework of the World Trade Organization, or in regional, bilateral, or even minilateral partnerships.
\end{abstract}

Keywords. Environment, trade, agreements, ratification, hypergraph, modeling, United Nations.

\subsection{INTRODUCTION}

Under the aegis of the United Nations (UN), most multilateral ${ }^{117}$ treaties are negotiated by about 200 sovereign States for years, and then are eventually signed and ratified by some or most of these States.

\footnotetext{
${ }^{117}$ Regional treaties concern restricted communities of States.
} 
Although negotiation processes are at the center of the research agenda in International Relations, these processes leading to ratifications, on the contrary, are still very little studied. However, the ratification processes vary according to the country considered, in particular according to the interactions among public and private, domestic and multinational actors, this alongside many other determinants (Lantis, 2009). In addition to this, ratification does not mean the full implementation of the international obligations contracted through the agreements, which ultimately depends on the true willingness of the State to meet these commitments, and to devote the means necessary to their achievement.

Although trade negotiations take place mostly outside the UN, they are directly connected to the UN legal and diplomatic framework. Multilateral, bilateral or minilateral arenas such as the European Union (EU), the World Trade Organization (WTO) (Falkner, 2015), the Triad NAFTA, the G7, the BRICs, the Trans-Pacific Partnership (TTP) or the Trans-Pacific Trade and Investment Partnership (TTIP) have proliferated ${ }^{118}$. Similarly, minilateral or regional arrangements also exist in the various environmental regimes (on climate change, protection and conservation of biological diversity, ocean resource management and governance, etc.) as illustrated by the examples of the regional agreements, specific conventions, such as the Arctic Council and the Antarctic System, to name only a few of them. Trade and the environment were usually treated in the UN negotiations as separate international regimes ${ }^{119}$ during the reconstruction of the Western liberal order or even after the collapse of the bipolar order in the 1990s. But the links between them are increasingly recognized in both regimes as a requisite to get closer to the conditions for sustainable development, according to the strengthening of the international obligations established by the multilateral agreements. The WTO agreement of 1995 is the most emblematic example ${ }^{120}$ of this trend. Thus, processes of juxtaposition, privatization and fragmentation of these two regimes (and complex of regimes) ${ }^{121}$ represent a challenge for the UN over the coming years (Karns et al., 2015). Both regimes are linked because the trade and environment agendas have never been so intertwined (UNEP, 2017a,b).

To better understand this dual evolution, this article analyzes the agendas of multilateral negotiations and the place / role of States on the basis of the ratifications of treaties that follow these negotiations. The interest of an analysis using mathematical modeling and the theory of international relations related to trade and environment is twofold. First, it is to test whether the UN manages to function as a reasonably homogeneous system, that is to say, to play the role of "constructor of the social world" to use the words of Barnett and Finnemore (2004). If the ratification of multilateral treaties shows a convergence of States parties to the two regimes, the contribution of the United Nations can be considered as significant. Then, the analysis of the results obtained will establish valid correlations concerning this trade-environment relation. If both of these assumptions are true, sustainable development - relying on the three pillars of economic viability, environmental preservation and social

\footnotetext{
${ }^{118}$ The European Union is the most successful political arrangement and the only one that covers the commercial and environmental agendas. The Triad composed by Washington, Brussels and Tokyo was only an informal arrangement to reinforce the emergence of Japan in the 1980s. NAFTA is the result of Washington's leadership on Toronto and Mexico. The TTP and the TTIP are both mega accords that suffered heavily with Donald Trump's trade policy since 2016. The G7 is the group of the most industrialized countries united to drive the global economy outside the UN framework. BRICS is the informal group of emerging countries - Brazil, Federation of Russia, India, China, South Africa- under Chinese leadership. The two latter are more economic than trade-oriented, but they do foster intra-group trade.

${ }^{119}$ According to Krasner (1983), p.141, it is "sets of implicit or explicit principles, norms, rules, and decisionmaking procedures around which actor expectations converge, in a variety of areas of international relations."

${ }^{120}$ The WTO is not part of the United Nations, but relations between the two organizations have been governed since 1995 by the "Arrangements for Effective Cooperation with Other Intergovernmental Organizations".

${ }^{121}$ The debate on international regimes took shape around the 1970s. Using functional, strategic, and organizational arguments, Keohane and Victor (2010) described a regime complex as "a loosely coupled set of specific regimes".
} 
justice - can be seen as a structuring concept of international relations, just like the affirmation by Shelton and Kiss (2007) concerning International Environmental Law. If the results are too contrasted, it would be wise to consider the UN as an epiphenomenon (Mearsheimer, 2001; Barnett and Finnemore, 2007; Viola and Franchini, 2018) playing only a marginal role. As a consequence, it may be argued that the sustainable development principle fails to structure both the international public law and the international relations.

In Section 11.2 we rapidly expose the logic that governs the elaboration and possible ratification of international treaties in trade and environment respectively. Then (Section 11.3) we present the data we use and the proposed analysis based on hypergraphs, defining this mathematical object and detailing the tools used in this study. In Section 11.4 we expose and compare the results of our analyzes carried out on the domains of environment and trade respectively. Section 11.5 discusses the contribution and limitations of the approach we have developed in the context of IR analysis, these limitations being mainly related to the specificity of the ratification dynamics according to the international regime approach.

\subsection{RATIFICATION OF TRADE AND ENVIRONMENTAL TREATIES}

\subsubsection{The UN convergence on trade and environment}

One objective of the UN is to ensure more cohesion to a global trade and environmental governance by setting the basic rights and duties for all the States members. Within the United Nations, seen as a normative and material structure ${ }^{122}$, a myriad of public and private actors meet (IISD / UNEP, 2005; Karns et al., 2015). From an institutional viewpoint, both areas - trade and environment - also shared a difficult start in the multilateral governance architecture. The International Trade Organization (ITO) could not be created following the refusal of the US Congress to ratify the charter in the late 1940s. More than three decades later, the United Nations Environment Program (UNEP) was established as the first step in building a real organization. Immediately after the 1992 Rio Summit, the World Trade Organization was created under the leadership of Washington, thus, confirming the predominance of the logic concerned with the regulation of trade over the one ensuring a sustainable management of the environment and natural resources. In response, in the year 2000, the UN orchestrated the global agenda through the Millennium Development Goals (MDGs) followed in 2015 by the Sustainable Development Goals (the SDGs or Global Goals) ${ }^{123}$, so as to build a more harmonious and favorable context to sustainable development up to 2030. Recently the UNEP was renamed UN Environment but without structural changes ${ }^{124}$.

\subsubsection{Three factors of the interlocking of the two regimes}

Despite the limitations posed by the separation of the trade and environmental regimes over the past seven decades, there are several simultaneous interlinking factors, especially embedded in political, economic and legal approaches. A first factor is the economic approach that has been adopted to improve the collective management of natural resources. The concern regarding neo-Malthusian approaches of raw materials shortages in function of the population explosion in some Third World countries, leading to significant market imbalances (Meadows et al., 1972), is at the origin of the 1972 United Nations Conference on the Human Environment (UNCHE). Over time, market instruments such as quotas, labels and certifications have been used more extensively in environmental regimes.

\footnotetext{
${ }^{122}$ According to the neoliberal and institutional research in International Relations, neo-realists, like Susan Strange (1998), prefer to describe the power structure as material.

${ }^{123}$ Including Goal 9 which deals with sustainable and inclusive industrialization.

${ }^{124}$ https://www.unenvironment.org/ Accessed 9 Feb 2018
} 
The Convention on International Trade in Endangered Species of Wild Fauna and Flora (CITES ${ }^{125}$ ) is an example of the use of market instruments to protect endangered species. Another example is the global climate regime, having created the flexibility mechanisms with the 1997 Kyoto Protocol and encouraged carbon markets, allowing entrepreneurs to participate directly in solutions for the mitigation of greenhouse gas impacts. In the forest quasi-regime (de Carvalho, 2012), REDD and REDD+ mechanisms have been designed to counter deforestation. Thus, under the 2015 Paris Agreement similar mechanisms have been proposed. At the Rio summit in 2012, the green economy was promoted as the new bridge between the commercial and environmental regimes ${ }^{126}$.

A second factor is based on the development of scientific knowledge. Among the key concepts linking both regimes, "sustainable development" was established in the Brundtland Report (1987) as a major concept triggering conciliatory efforts to promote international cooperation and effective multilateralism, linking trade, social justice and the environment. In the same vein, the concept of "global commons" established by the scientific community (Ostrom et al., 2002), provides a framework for a more sustainable management of shared resources. It also agreed on the concept of an "Anthropocene" (Crutzen and Stoermer, 2003; Biermann et al., 2012), reinforcing human responsibility to treat the environment as a set of goods and to consider the importance of ecosystem services (Nakicenovic et al., 2016).

A third factor in the overlap of the two regimes has been the recognition of legal principles, starting with the sustainable development. Trade and environment share the logic of State differentiation used in the framework of the GATT and the WTO with regard to the least developed countries: the States are sovereign but they possess asymmetrical capacities and different historical development trajectories, hence the principle of common but differentiated responsibilities consolidated in environmental law, especially in the climate regime. The Cartagena Protocol ${ }^{127}$ on Biosafety to the Convention on Biological Diversity corroborated the precautionary principle, against the principle of non-discrimination of the WTO. As a result, countries had the right to refuse the purchase of living genetic modified organisms, in order to avoid risks that are still poorly known to consumers' health and the risks of biological contamination. The WTO Dispute Settlement Body further developed the precautionary principle and contributed to its inclusion in commercial litigation. The polluter-pays principles and the right to development, advocated by the countries of the South, are also present in the UN talks on trade and environment.

\subsubsection{However two orthogonal directions}

The environmental logic was previously concerned with issues that were treated as exclusive problems of sovereign States, such as pollution or the appropriation and consumption of raw resources. It then turned to more cross-border collective action issues (such as the fight against acid rain and oil spills), and then to global issues (such as the loss of biodiversity, climate change and its impacts, marine resource management, or nuclear contamination). Thus, the construction of international regimes since the last century attests to the internationalization of environmental issues, whose central concept was the ecological interdependence (OECD, 1982). States are asked to accept negative international obligations such as not to cause harm beyond their national jurisdiction, and positive obligations such as to prevent, cooperate, inform, repair the damages caused. Environmental agreements are therefore negotiated for the sake of preservation (fragile or threatened ecosystems), conservation (the most rational use of resources possible) or collective management, on behalf of present and future

\footnotetext{
${ }^{125}$ CITES: https://cites.org/eng/disc/text.php Accessed 9 Feb 2018

${ }^{126} \mathrm{https} / / /$ sustainabledevelopment.un.org/index.php?menu=1225 Accessed 9 Feb 2018

127 Cartagena Protocol, adopted on 29 January 2000 and entered into force on 11 September 2003: http://bch.cbd.int/protocol/ Accessed 9 Feb 2018
} 
generations. Since 1972 (UNCHE, Stockholm), the UN has been organizing summits to promote the sustainable development agenda, the main ones being held in 1992 (Rio de Janeiro Earth Summit), 2002 (World Summit on Sustainable Development, Johannesburg) and 2012 (United Nations Conference on Sustainable Development - or Rio+20).

The commercial logic is quite distinct (see Table 11.1). First, it is based on the lex mercatoria, European medieval customary law, with its own codes of conduct. Then, its main purpose is not to protect the Planet or its natural resources, but to build a material and normative structure for free trade and, to a lesser extent, the integration of markets at the global level. Its stage of internationalization began five centuries earlier, with the great European navigators. Private and public actors interact intensely in complex and asymmetrical interdependencies. Agreements in the UN framework are less numerous and effective than those established outside it. A strong assumption is that the trading powers prefer to negotiate with each other, like the United States and China, because the South forms a majority in the UN organizations (Devin and Smouts, 2012) and the WTO. As a consequence, the Doha Round $^{128}$ has been stalled for too long following several deep disagreements, aggravated by the 2008 crisis on the Euro-Atlantic axis. This partly explains why these States will not appear very much in the graphs below.

Tab. 11.1 Compared main ingredients of norms creation

\begin{tabular}{|c||c|c|}
\hline & Environment & Trade \\
\hline \hline Main actors & UN, EU & USA, EU, China \\
\hline $\begin{array}{c}\text { Main International } \\
\text { Organizations }\end{array}$ & UNGA, UNEP, UNDP, IPCC & GATT, UNIDO, UNCTAD, WTO \\
\hline Highlights & $1972,1992,2002,2012$ & $70 \mathrm{~s}, 1994$ \\
\hline International Law & Rather declaratory (soft law) & Rather mandatory (hard law) \\
\hline Paradigms & $\begin{array}{c}\text { Sustainable development, } \\
\text { global commons, } \\
\text { differentiated responsibilities, } \\
\text { MDGs and Global Goals }\end{array}$ & $\begin{array}{c}\text { Free-trade, non-discrimination, } \\
\text { regional integration, green } \\
\text { economy, blue economy }\end{array}$ \\
\hline
\end{tabular}

Taking into account countries individually since 1972, the two largest economies in the world, industrial and technological powers, polluters and emitters of greenhouse gases are the United States of America and China. Today they are also the biggest investors in technologies related to the "green economy", in particular to ensure their energy security. The USA is also the largest promoter of free trade since the establishment of the United Nations, but in environmental regimes it does not ratify most important agreements, despite its decisive participation. In addition, President Donald Trump denounced the Paris Agreement on Climate Change ${ }^{129}$ in June 2017. On the contrary, China participates in the environmental debates and ratifies the major agreements, which does not constitute a guarantee that the Asian giant will implement them. It also participates in trade talks, bringing the G77 / China, the BRICs and the G20 as central players, with increasing weight since its official WTO entry and the implementation of Ji Xiping's active diplomacy with the 2017 Rejuvenation Plan.

The European Union, for its part, is the only stable community in the environment regime, playing a central role in its region and within the United Nations (see below). It is irrefutably a central player in environmental and commercial law and can therefore be considered as a normative power in these two areas (Laïdi, 2006), even after the conclusion of the BREXIT ${ }^{130}$. However, the EU is entangled in and weakened by current crises and contemporary Euro-skeptic rhetoric.

\footnotetext{
${ }^{128}$ Last WTO round of negotiations began in 2001, the Doha Development Program aimed to reduce trade barriers and facilitate the expansion of world trade.

${ }^{129} \mathrm{https} / / /$ ec.europa.eu/clima/policies/international/negotiations/paris fr Accessed 9 Feb 2018

${ }^{130}$ The exit of the United Kingdom from the European Union voted in 2016.
} 


\subsection{DATA ANALYSIS WITH HYPERGRAPHS}

Does the analysis of the history of the ratification of multilateral environmental and trade agreements corroborate the landscape of international relations just described? Can some information on ratifications be used to produce empirical evidence based on accessible and open data, about this divide between the logic of preserving the environment and the logic of growth through international trade? In order to answer these questions which concern as much a theme of globalization as a methodological reflection, we will, first of all, recall and present some results obtained on the ratification of the MAEs (Sec 11.3.1) and then introduce (Sec.11.3 .2) hypergraphs and the associated analysis procedure (Sec.11.3.3).

\subsubsection{Previous results}

In a previous work (Boulet et al., 2016), we analyzed 3550 ratifications related to 48 multilateral environmental agreements (MEAs) listed in chapter XXVII «Environment » of the United Nations Treaty Collection ${ }^{131}$. The analysis covering a period of 35 years (1979-2014) involves more than 195 countries (or entities like the EU with a mandate to sign and ratify these agreements). A first simple graph built on the basis of a rule ${ }^{132}$ of succession of ratifications has made it possible to identify communities of MEAs emerging from this ratification dynamics and to interpret these communities of treaties according to the fundamental interests of the signatory countries (Boulet et al., 2016). A second rule ${ }^{133}$, somehow dual to the first, leads to build another graph where the vertices are the countries. Using various algorithms, we identify informal communities of countries ${ }^{134}$ emerging from this ratification history (see Table 11.2) and represent them on a geographical map (Figure 11.1).

Tab. 11.2 Main country communities underlying the MEAs ratifications graph (see Fig.11.1)

\begin{tabular}{|c|c|}
\hline $\begin{array}{l}\text { Community } \\
\text { (colour on Fig.11.1) }\end{array}$ & Members \\
\hline $\begin{array}{l}\mathrm{C} 1 \\
38 \text { members } \\
(\text { red })\end{array}$ & $\begin{array}{l}\text { Austria, Belarus, Belgium, Bulgaria, Canada, Croatia, Cyprus, Czech Rep., } \\
\text { Denmark, Estonia, EU, Finland, France, Germany, Greece, Hungary, Ireland, } \\
\text { Italy, Japan, Jordan, Latvia, Liechtenstein, Lithuania, Luxembourg, } \\
\text { Netherlands, Norway, Poland, Portugal, Romania, Russian Fed., Slovakia, } \\
\text { Slovenia, Spain, Sweden, Switzerland, Ukraine, UK, USA }\end{array}$ \\
\hline $\begin{array}{l}\mathrm{C} 2 \\
32 \text { members } \\
\text { (blue) }\end{array}$ & $\begin{array}{l}\text { Angola, Bahrain, Bangladesh, Bolivia, Burundi, Chad, Colombia, Comoros, } \\
\text { Congo, Gambia, Ghana, Guinea, Haiti, Iran (Islamic Rep.), Israel, Kazakhstan, } \\
\text { Kyrgyzstan, Madagascar, Mauritania, Micronesia (Fed.), Mozambique, } \\
\text { Myanmar, Namibia, Pakistan, Palau, St. Vincent \& Grenadines, Suriname, } \\
\text { Swaziland, Turkmenistan, Vanuatu, Yemen, Zimbabwe }\end{array}$ \\
\hline $\begin{array}{l}\text { C3 } \\
22 \text { members } \\
(\text { green })\end{array}$ & $\begin{array}{l}\text { Antigua \& Barbuda, Brazil, Chile, China, Ecuador, El Salvador, Ethiopia, Fiji, } \\
\text { Guatemala, India, Kenya, Lesotho, Malaysia, Mali, Mauritius, Mexico, } \\
\text { Morocco, Paraguay, Tanzania (Un. Rep.), Tunisia, Venezuela (Rep.), Zambia }\end{array}$ \\
\hline $\begin{array}{c}\mathrm{C} 4 \\
16 \text { members }\end{array}$ & $\begin{array}{l}\text { Algeria, Barbados, Cambodia, Cameroon, Cuba, Congo (Dem. Rep.), } \\
\text { Dominican Rep., Equatorial Guinea, Eritrea, Honduras, Kuwait, Lao (Dem. }\end{array}$ \\
\hline
\end{tabular}

\footnotetext{
${ }^{131}$ https://treaties.un.org/pages/Treaties.aspx?id=27\&subid=A\&lang=en Accessed 9 Feb 2018

${ }_{132}$ There is a directed link from agreement A1 to agreement A2 if A2 is the first agreement ratified after agreement $\mathrm{A} 1$ by a same country.

${ }_{133}$ There is a directed link from country $\mathrm{C} 2$ to country $\mathrm{C} 1$ if $\mathrm{C} 2$ is the first country after $\mathrm{C} 1$ to have ratified the same MEA.

${ }^{134}$ We describe as "stable" the informal communities presented here in the sense that the list of countries that each one of them contains is found whatever the algorithm used.
} 


\begin{tabular}{|c||l|}
\hline (yellow) & Rep.), Niger, Papua New Guinea, St. Kitts \& Nevis, Sudan \\
\hline $\begin{array}{c}\text { C5 } \\
16 \text { members } \\
\text { (grey) }\end{array}$ & Arab Emirates (Un.), Bahamas, Bhutan, Dominica, Kiribati, Marshall Islands, \\
Oman, Saudi Arabia, Senegal, Seychelles, Singapore, Sri Lanka, St. Lucia, \\
Syria (Arab Rep.), Uganda, Uzbekistan
\end{tabular}

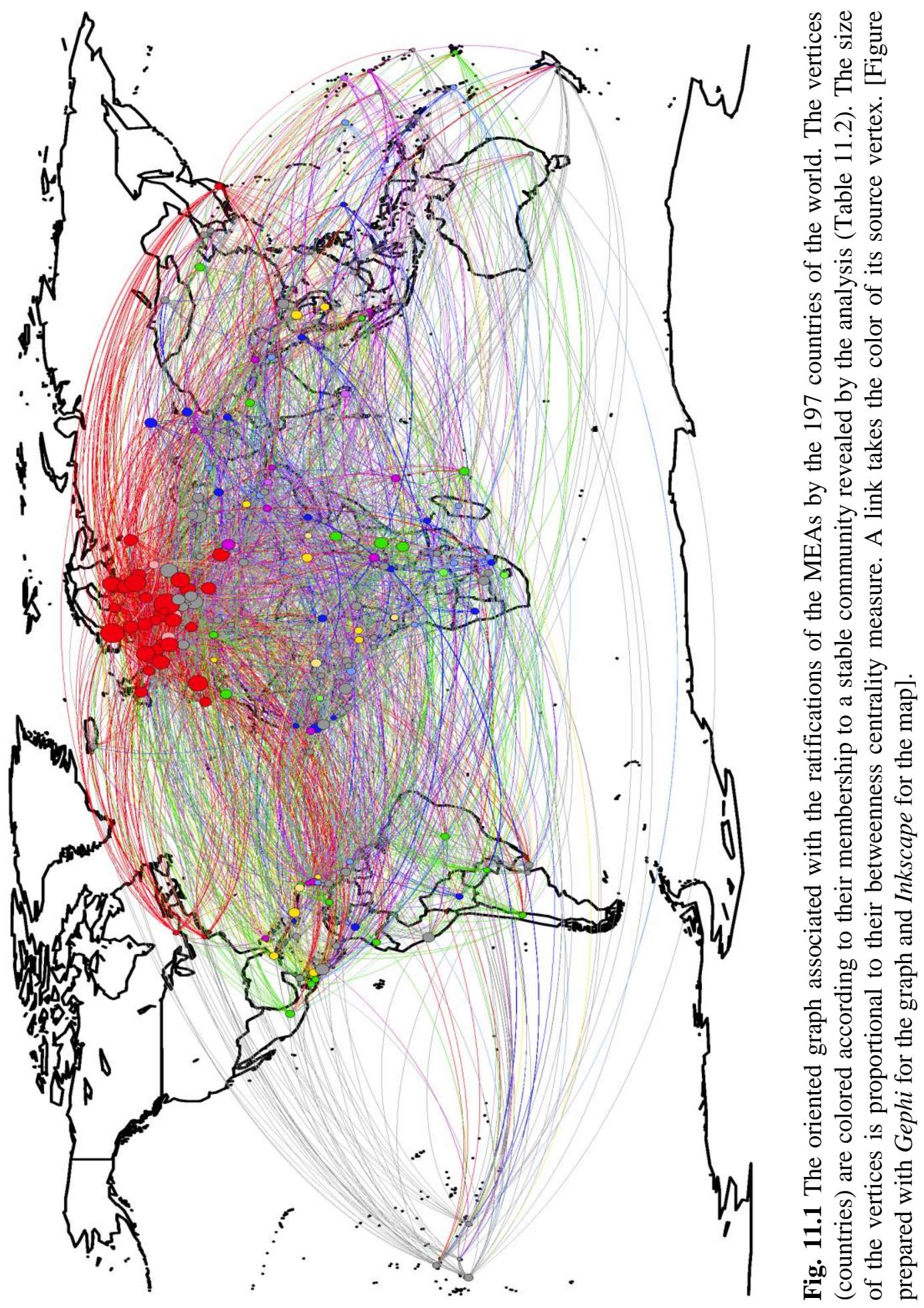


The most salient result is the presence of the community gathering mainly Euro-Atlantic countries. Through the inclusion of all its States members the European Union is the only formal institution included in such an informal community ${ }^{135}$ emerging from 35 years of ratification of MEAs. The calculation of the centralities of the vertices of the graph underlines even more the predominant place of European countries, in particular countries from Northern Europe and Norway (see Table 11.3).

Tab. 11.3 Most central countries in the graph of environmental ratifications

\begin{tabular}{|c|c|}
\hline $\begin{array}{c}\text { Closeness centrality } \\
\text { (rank) }\end{array}$ & $\begin{array}{c}\text { Betweenness centrality } \\
\text { (rank) }\end{array}$ \\
\hline 1. Norway & 1. Hungary \\
\hline 2. France & 2. Norway \\
\hline 3. Hungary & 3. Lithuania \\
\hline 4. Luxembourg & 4. Belgium \\
\hline 5. Spain & 5. Austria \\
\hline 6. Netherlands & 6. Spain \\
\hline 7. Finland & 7. Estonia \\
\hline 8. Lithuania & 8. Romania \\
\hline 9. Bulgaria & 9. Netherlands \\
\hline 10. Denmark & 10. Finland \\
\hline
\end{tabular}

From now our goal is twofold: a) to enrich and improve this graph-based approach by introducing hypergraphs as a way to overcome problems related to the representation and modeling of simultaneous ratifications that are occurring recurrently in the database (see Sec. 11.4.1); b) to explore what the hypergraph-based approach could bring to two highly differentiated areas of international policy and how it would be useful to conduct critical comparative analyzes (this is done on a small scale since we consider only the UN trade treaties).

\subsubsection{Directed graphs and hypergraphs: definitions}

Let us start by recalling definitions of graphs and hypergraphs. A graph is a set $\mathrm{V}=\left\{\mathrm{v}_{1}, \mathrm{v}_{2}, \ldots, \mathrm{v}_{\mathrm{n}}\right\}$ of vertices and a set $\mathrm{E}$ of edges, an edge being a subset of $\mathrm{V}$ with two elements. This simple (one often speaks of a simple graph) and binary (there exists or not a relation between two vertices) structure can be enriched by the addition of weight on the edges (weighted graph) or by the addition of an orientation on the edges (directed graph). So, a directed graph is defined by a set $\mathrm{V}=\left\{\mathrm{v}_{1}, \mathrm{v}_{2}, \ldots, \mathrm{v}_{\mathrm{n}}\right\}$ of vertices and a set $\mathrm{E}$ of directed edges, a directed edge being defined by a source vertex and a target vertex. Figure 11.2 illustrates these definitions.

Fig. 11.2 Top: a graph whose set of vertices is $\{1,2,3,4,5,6\}$ and whose set of edges is $\{\{1,2\},\{2,3\},\{2,4\},\{3,5\},\{4,5\},\{5,6\}\}$. Bottom: A directed graph on the same set of vertices

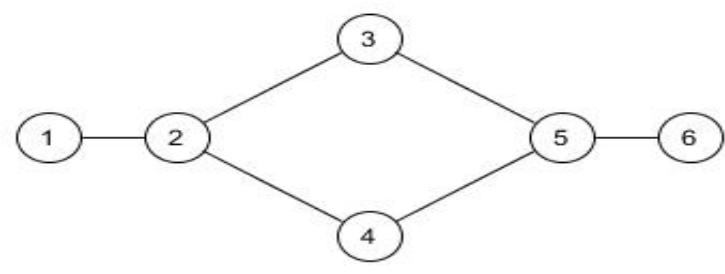

\footnotetext{
${ }^{135}$ Indeed, none of the other formal communities (economic, political, strategic, security, ...) - ASEAN, BRICs, African Union, MERCOSUR, ... - appear in any of the countries communities induced by the history of ratifications.
} 
having 6 directed edges represented by arrows going from the source to the target

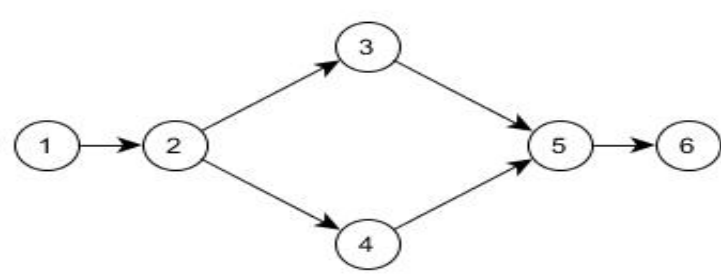

A hypergraph is defined by a set $\mathrm{V}=\left\{\mathrm{v}_{1}, \mathrm{v}_{2}, \ldots, \mathrm{v}_{\mathrm{n}}\right\}$ of vertices and a set $\mathrm{E}$ of hyperedges, a hyperedge being a subset of $\mathrm{V}$ with several (two or more) elements. A directed hypergraph is a set $\mathrm{V}=\left\{\mathrm{v}_{1}, \mathrm{~V}_{2}, \ldots, \mathrm{V}_{\mathrm{n}}\right\}$ of vertices and a set $\mathrm{E}$ of directed hyperedges, a directed hyperedge being defined by a set of source vertices and set of target vertices; these source set and target set being disjoint. Figure 11.3 illustrates these definitions.

Fig. 11.3 Top: a hypergraph whose set of vertices is $\{1,2,3,4,5,6\}$ and whose set of hyperedges is $\{\{1,2\},\{2,3,4\},\{3,4,5\},\{5,6\}\}$. Bottom: a directed hypergraph on the same set of vertices and having 4 hyperedges represented par arrow hyperedges going from sources toward targets.

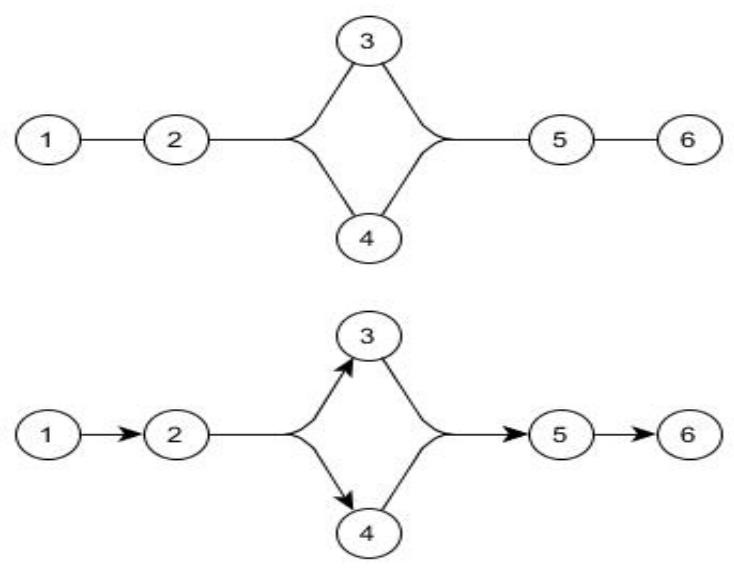

\subsubsection{Analysis of a directed hypergraph}

Our analysis of a directed hypergraph is based on its incidence matrix. The incidence matrix B of a directed hypergraph on $n$ vertices and $m$ directed hyperedges is the $n \times m$ matrix whose rows are labeled by vertices from 1 to $n$ and whose columns are labeled by the directed hyperedges from 1 to $m$. The $(i, j)$ entry of B is 1 if vertex $i$ is a target of hyperedge $j,-1$ if vertex $i$ is a source of hyperedge $j$ and 0 otherwise (Gallo et al., 1993). Note that the sign is conventional and our analysis is not influenced by these conventions. The matrix B can be seen as an individual / variables matrix where individuals are the vertices and variables are the directed hyperedges taking values 0,1 or -1 . The mean of a variable is 0 if and only if the directed hyperedge has as many sources as targets. In multidimensional descriptive statistics, it is often customary to center-reduce variables in order to erase the effects of scales between variables expressed in different units or with different orders of magnitude. Here it is not useful because it is interesting to highlight hyperedges with multiple sources and goals.

A principal component analysis based on the diagonalization of the matrix $B^{T} B$ allows defining new orthogonal factors which are linear combinations of original variables given by the $k$ eigenvectors associated to the $k$ largest eigenvalues of $B^{T} B$. So, we can embed the rows of $\mathrm{B}$ in a Euclidean space of dimension $\mathrm{k}$. The vertices of the directed hypergraph are then points of $3^{k}$ whose coordinates are given by $B u, u$ being an eigenvector of $B^{T} B$. Once the vertices of the directed hypergraph are embedded in $3^{k}$ we apply usual methods of unsupervised clustering such as k-means ascending hierarchical clustering in order to detect some communities of vertices of our directed hypergraph ${ }^{136}$. Another point of view is spectral embedding: the vertices of the directed hypergraph are embedded in

\footnotetext{
${ }^{136}$ The choice in the convention of the sign in the definition of B has no effect in this approach, indeed if $\tilde{B}$ the matrix built with the converse convention we have $\tilde{B}=-B$ and $\quad{ }^{t} \tilde{B} \tilde{B}={ }^{t} B B$.
} 
$3^{k}$ and the coordinates are given by the eigenvectors of $B B^{T}$. When the hypergraph is a graph, $B B^{T}$ is the Laplacian matrix and we recognize the usual spectral clustering (von Luxburg, 2007).

Thanks to this embedding in $3^{k}$, the central vertices can be defined as the vertices closest to the center of gravity (barycenter) of the scatter-plot of $3^{k}$. The definition of this notion of centrality differs from the usual notions of centrality of betweenness of closeness. In order to avoid any confusion, we will call it embedding centrality.

\subsection{Hypergraph-BaSed Comparison of EnVironment and Trade RATIFICATIONS}

\subsubsection{Modeling by hypergraphs}

A weak point of modeling by simple graphs is that it artificially increases the degree of the vertices representing the countries that have proceeded to simultaneous ratifications, thus being able to bias some indicators, in particular the indicators of centrality. To overcome this problem, we proceed to a modeling based on directed hypergraphs where there is a directed hyperedge from a source set $\mathrm{A}$ of vertices (countries) and a target set $\mathrm{B}$ of vertices if and only if all the countries in A have ratified simultaneously a treaty just before countries in B ratify simultaneously that treaty. Sets A and B may contain a single country. Thus, simultaneous ratifications do not increase the degree of the vertices in A or B as can be seen on Figure 11.4 which is an example of hypergraph construction for a single treaty.

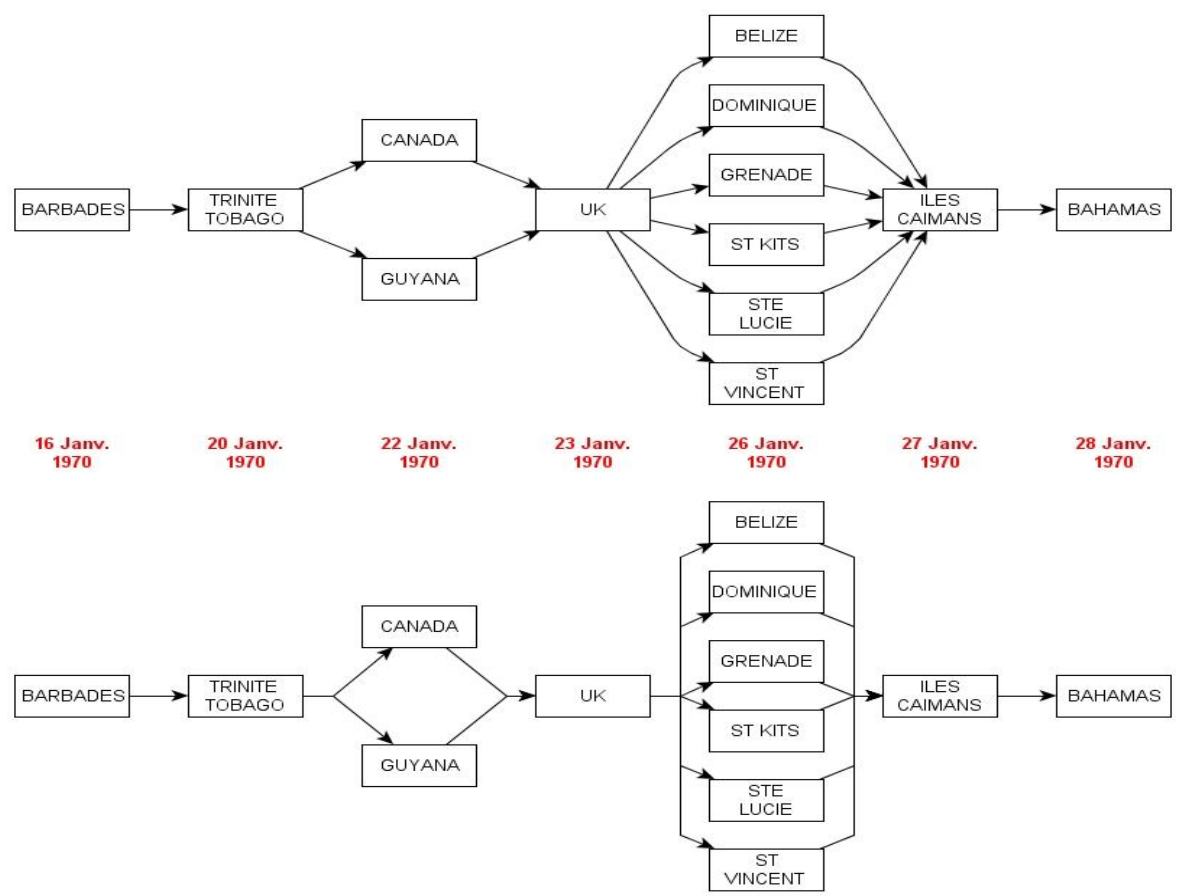

Fig. 11.4 Top: example of modeling by a directed graph of a few successive ratifications of the agreement establishing the Caribbean Development Bank. Bottom: modeling by an oriented hypergraph of the same data

The hypergraph resulting from a set of treaties is then the union of hypergraphs built for each treaty: the vertices (resp. hyperedges) are the union of the set of vertices (resp. hyperedges) of hypergraphs for each treaty. Let us note that this union is not the disjoint union of hypergraphs because the set of vertices are not disjoint. 


\subsubsection{Results in the field of the environment}

We produced the hypergraph induced by the same data used in the work presented previously, say the 3550 ratifications of 48 MEAs. The method exposed in Section 11.3.3 provides a clustering of the vertices (thanks to an embedding followed by an ascendant hierarchical clustering). A large community clearly that emerges (cf. Table 11.4) containing countries from continental Europe, among which 27 are countries of the EU (only Malta is not classified in this group and UK is a member of the EU and belongs to this group over the considered time period).

Tab. 11.4 Countries constituting a community in the hypergraph of environmental ratifications

\begin{tabular}{|llllll|}
\hline Albania & Austria & Belarus & Belgium & Bulgaria & Croatia \\
Cyprus & Czech Rep. & Denmark & Estonia & EU & Finland \\
France & Germany & Greece & Hungary & Ireland & Italy \\
Latvia & Liechtenstein & Lithuania & Luxembourg & Moldava & Netherlands \\
Norway & Poland & Portugal & Romania & Serbia & Slovakia \\
Slovenia & Spain & Sweeden & Switzerland & UK & Ukraine \\
\hline
\end{tabular}

This community stands out clearly in the sense that the best partitioning is a bipartition with on the one hand these 36 countries of continental Europe and, on the other hand, the rest of the world. Other partitions resulting from division at different levels of resolution (thus varying the number of communities) do not reveal other communities corresponding to politico-economic groups or formal communities.

According to the embedding centrality, most central countries are European countries (Figure 11.5). These results correspond to the strengthening of multilateral institutions through the development of public international law in general and environmental law in particular promoted by these countries. From the beginning of the twentieth century, not only these Western countries are the main sources and architects of an articulation of doctrines, institutions and principles relating to the environment, but they also served as models to other countries keen to improve the legal and political framework of their public action.

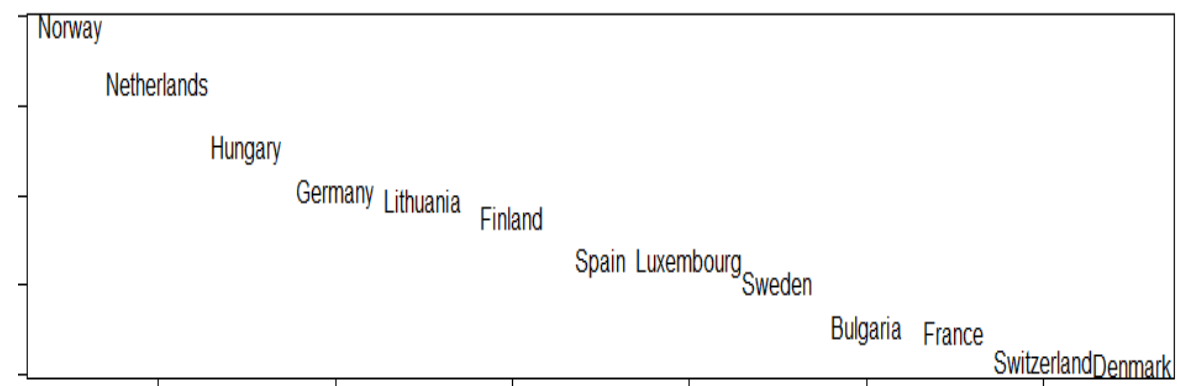

Fig. 11.5 List of the most central countries (ranked from left to right by decreasing embedding centrality) in the hypergraph of ratifications of UN environmental agreements (1979-2014)

The precautionary principle, for example, is inspired by German regulations, while the polluter-pays principle has been consolidated by the OECD. Both have been adopted in multilateral and national texts on other continents. In addition, the first ministries of the environment were created in developed countries, while other states followed after the UNCHE. Europeans, having undertaken to develop their environmental law earlier than the rest of the world in general, and collectively in the context of the development of EU law, tend to ratify environmental agreements at the same pace. Our results 
obtained from the hypergraph-based analysis corroborate the thesis that the EU is both a material and normative structure (Laïdi, 2006) in environmental matters.

As far as the rest of the world is concerned, most of the time regional organizations have failed to generate deep and effective cooperation to address environmental challenges, thus regional governance is less obvious. The case of the governance of the Amazon is a typical example: the Amazon Cooperation Treaty ${ }^{137}$ signed in 1978 may suggest that regional cooperation on environmental issues is effective, while its impact on the foreign policies of the Member States has always been and remains very limited. It is therefore not surprising that they do not form regional communities appearing in the graphs constructed from ratifications.

\subsubsection{Results in the field of trade}

We apply the same method of modeling and clustering for UN trade-related treaties. We have 834 ratifications from 1963 to 2014, covering 23 commercial treaties listed in Chapter X of the United Nations Treaty Collection. There is a large, heterogeneous community (Table 11.5) that contains none of the world's top 10 economic powers. We have another, smaller, emerging community that contains three of the world's major economic powers (China, Japan and USA in community C2 in Table 11.5).

Tab. 11.5 Three communities - $\mathrm{C} 1$ to $\mathrm{C} 3$ - detected in the hypergraph of ratifications of UN trade agreements

\begin{tabular}{|l|l|}
\hline C1 & $\begin{array}{l}\text { Antigua and Barbuda, Azerbaïdjan, Bahreïn, Bolivia, Bosnia and Herzegovina, Brunei, Bulgaria, } \\
\text { Costa-Rica, Croatia, United Arab Emirates, Eritrea, Estonia, Greece, Guatemala, Hong-Kong, } \\
\text { Cayman Islands, Marshall Islands, Solomon Islands, Turks and Caicos Islands, British Virgin } \\
\text { Islands, Iceland, Kiribati, Latvia, Lithuania, Malta, Micronesia, Monaco, Montserrat, Nauru, } \\
\text { Nicaragua, Niue, Oman, Palau, Portugal, Czech Republic, San Marino, Serbia, Slovakia, South } \\
\text { Sudan, East Timor, Turkmenistan, Tuvalu, Vanuatu }\end{array}$ \\
\hline C2 & $\begin{array}{l}\text { Belgium, China, Denmark, Egypt, Gabon, Guinea, Japan, Liberia, Libya, Malaysia, Republic of } \\
\text { Korea, Thailand, USA, Zambia }\end{array}$ \\
\hline C3 & $\begin{array}{l}\text { Comoros, Gambia, Honduras, Iraq, Lesotho, Malawi, Niger, Qatar, Samoa, Senegal, Vietnam, } \\
\text { Yemen }\end{array}$ \\
\hline
\end{tabular}

Concerning the embedding centralities (shown in Figure 11.6), we have a central position of some African countries (there are 5 treaties related to Africa), the USA and China being at the 6th and 9th ranks respectively.

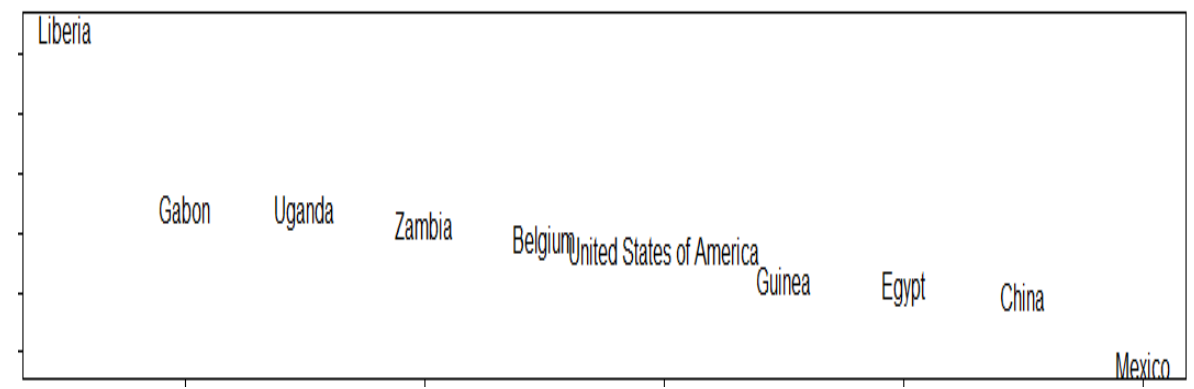

Fig. 11.6 List of most central countries (ranked from left to right by decreasing embedding centrality) in the hypergraph of ratifications of UN trade agreements

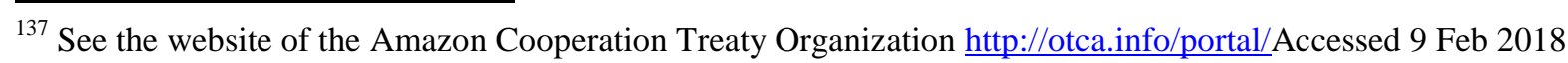




\subsubsection{Environment versus Trade results}

The main information concerning the ratification data of environmental agreements and UN trade agreements discussed here are summarized in Table 11.6. Not surprisingly the number of entities that have ratified the environmental and trade agreements considered here is almost the same and covers all sovereign nations that have existed in recent decades ${ }^{138}$. The average number of ratifications per treaty (or agreement) is twice as high for the environment than for trade. The most plausible explanation joins some crucial points of the analysis made previously: the inventory of multilateral environmental agreements made by the $\mathrm{UN}$ is representative of the efforts of the international community to take in consideration issues related to environmental protection, of course, with the limitations that we know. On the contrary most of the major commercial agreements are made outside the UN framework. Moreover, many trade agreements are established on a regional or interregional scale (such as the EU, NAFTA or TPP mentioned in Sec. 11.2), and not on a global scale as it is the case, for example, for major environmental conventions (in particular on climate change, biological diversity, ozone layer, etc.).

Tab. 11.6 Main information concerning the ratification data

\begin{tabular}{|l|c|c|}
\hline & Environment & Trade \\
\hline \hline Period studied & $1979-2014$ & $1963-2014$ \\
\hline Number of agreements (identified by the UN) & 48 & 23 \\
\hline Number of "countries" (vertices) & 197 & 198 \\
\hline Number of ratifications & 3550 & 834 \\
\hline Number of non-simultaneous ratifications & 3334 & 717 \\
\hline Number of hyperedges & 3286 & 694 \\
\hline
\end{tabular}

The specificity of the ratification process in the parliaments of each country should also be taken into account to explain observed differences in environmental versus trade ratification. If they are well structured, the work of analysis and the parliamentary debate run their course, and average ratification times for each agreement should be similar regardless of the area concerned. In this regard the functioning of parliamentary bureaucracy is a central variable, without forgetting that political processes are anything but linear and neutral. An opinion leader or a clever politician, depending on his political affiliation, may tip the balance to accelerate the ratification or to hinder it ${ }^{139}$. As it is the executive power that prepares the mandate to negotiate and signs the agreement abroad, and then it is the legislative power that ensures the process of ratification so that the head of state can ratify it, it is necessary to look more closely at the interaction of these powers and their interplay.

Considering the States as unitary and rational actors, in a utilitarian approach, a plausible hypothesis based on the work of Abbott and Snidal (2000) to explain a differentiated dynamic in environmental versus trade ratification, is that international obligations related to the environment are vague and often do not require delegation of authority from signatory States. The calculation of their economic impact might guide the decision to apply them at the national level but at a later stage. On the contrary obligations arising from the ratification of trade agreements are stipulated with precision and can be used by the partners regardless of the will of the application of a signatory country. This means that signatories have less control over the use of trade agreements. Now if we consider, as did Moravcsik

\footnotetext{
${ }^{138}$ A more detailed analysis will have to take into account the appearance and the disappearance of States and to establish the comparisons of graphs over the same time period.

${ }^{139} \mathrm{~A}$ research track to explore in political science would be to compare whether left-dominated parliaments vote on environmental treaties more quickly and those dominated by the liberal right, on the contrary, make trade treaties a priority. This is beyond our analytical objective and would only be useful in some countries, but probably not for the political regimes of China and Russia. Moreover, the left / right divide is no longer as clear as in the last century in the West.
} 
(1997), that the national interest is the result of a recurrent balance of power between intra-national actors, environmental issues can be considered as less controversial, risky and expensive than commercial ones, or just less important among the various conflicts of interest that States have to manage. Finally, in the event of non-compliance with commercial standards, a country may be sanctioned by its trading partner or an international / regional tribunal, a situation that is unparalleled in the environmental field. States can also push for others to ratify agreements more quickly. In the trade regime, this practice is frequent, the threat of the use of economic or financial coercion coexisting with the promise of loans and other types of assistance. The United States and China are two different models of the same practice. The EU is known for its practice of trying to impose rules on its trading partners ${ }^{140}$.

We observe that the percentage of simultaneous ratifications is more than twice as high in the field of trade $(14 \%)$ than in the field of the environment $(6 \%)$. Some factors contribute to this phenomenon, such as the fact that trade-related treaties are previously negotiated following concrete interests and reciprocity, whereas in the case of the environment, interests are larger, costs can be immediate and important, but the benefits are diffuse. Another explanation is that the national construction of interest (the calculation of gains / concessions) is more objective in trade agreements, and so are the lobbies from private actors.

The obvious differences in the structure of the hypergraphs associated with the environment and the trade consist of the difference of the central countries exhibited (the 10 most central countries for the environmental ratifications are not the most central ones for trade ratifications) and of the heterogeneity of the communities extracted in the field of the trade, while in the field of the environment there is clearly a community of European countries that we interpret as an expression of a diplomatic leadership. The more peripheral countries in global trade ratify for three main reasons, either the hope of creating a legal framework more protective of their national economy, or because they believe that they must participate in all the multilateral mechanisms with a view to their integration into value chains or because they have been under pressure from influent trading partners. Ratifying a commercial treaty means accepting to play the game, exposing oneself to others and to international obligations. Ratifying an environmental treaty implies keeping the image of a State which makes the fair effort to contribute to the global sustainable development.

\subsection{DISCUSSION}

In the research agenda of international relations there was a time when the fields of trade and the environment were treated as being hermetically separated. The former belonged to high politics, while the latter was not a priority (low politics) in multilateral agendas (Battistella, 2009). Since the 1970s, the rise of transnational corporations has led to the paradigm of a complex interdependence (Keohane and Nye, 1977), as asymmetric as it is inevitable. It was necessary to analyze the phenomenon of globalization and the intensification of trade flows, especially between the members of the "Triad" (Ohmae, 1985) formed by Western Europe, the United States and Japan, in the context of the emergence of the latter as an industrial power during the Cold war.

In reaction to the Triad, the countries of the South, named "Third World" in the bipolar order, created the G77 / China to promote their right to development in organizations such as the General Assembly of the UN (UNGA), UNCTAD or UNIDO ${ }^{141}$. In addition, several UNGA resolutions have been voted

\footnotetext{
${ }^{140}$ The carbon tax for commercial aviation is an interesting case of failure of this type of strategy (EU-ETS).

141 United Nations Conference on Trade and Environment and the United Nations Industrial Development Organization. UNIDO, for example, is now using the platform "Inclusive and Sustainable Industrial Development". See https://isid.unido.org/index.html. Accessed 9 Feb 2018.
} 
by a majority of Third World countries to ensure their right to development. Among the most emblematic resolutions - by their content and not by their force - were those of 1974 establishing the "new international economic order" (resolutions 3201 [S-VI] and 3202 [S-VI]).

It is precisely in this context of strong economic cleavage between the North and South and ideological cleavage between the East and West that the UN has set up the Conference on the Human Environment (UNCHE), in Stockholm in 1972. In this framework, the issue was to analyze the growing role of those James Rosenau (1990) has called 'sovereignty-free actors' and their interaction with States, in a real "turbulence in international politics" articulated between macro, micro and macro-micro levels. Barely a decade later, global politics has changed completely according to a power shift from the West to Asia (Hoge, 2004; Hearn, 2016). The complex interdependence has deepened when the Triad and the Third World gave way to emerging countries, especially China and India. In the field of trade and finance, these countries will form the BRICs. In the climate agenda, they will form the BASIC ${ }^{142}$. These two groups are more or less formal alliances that were supposed ephemeral at the time of their creation. Regarding environmental talks, despite the persistence of the North / South cleavage due to obligations to finance development and technology transfers, there are no formal groups of countries comparable to those of trade. There is no regional governance, with the exception of the EU which plays a key role as a norm shaper in trade and in environmental negotiations ${ }^{143}$.

In this global context, our hypergraph-based analysis of the ratification of trade and environmental agreements supports the idea that their logic is different (IISD and UNEP, 2014), although the key players are roughly the same. Compared to more traditional analysis of the dynamics of ratification, this approach combining modeling and International Relations theory presents three main contributions. First, it contributes to the interdisciplinary dialogue, particularly between international law and political sociology, allowing results to be compared over a long period of time. It also allow testing the supposed practices and strategies regarding the ratification of international treaties (see e. $\mathrm{g}$. Chang, 2016). Finally, it allows to compare the environmental logic and the trade logic (here in the UN framework) to spot the key States involved. Thanks to the analysis of the political context, we have show that the multilateral summits promoted by the UN have a considerable impact on the signing of treaties, but not necessarily on their ratification or implementation.

\subsection{CONCLUSION}

The comparison of the dynamics of ratifications of two regimes - environment and trade - within the United Nations framework shows that they follow parallel evolution, in spite of the strengthening of their intertwining since the 1990s, notably from an institutional point of view. The UN has a central role in the environmental agenda, which explains the recurrence of multilateral summits since 1972 and the number of agreements signed and ratified by almost all members of the organization. For the trade agenda, on the contrary, the role of the United Nations is becoming less and less important, and the multilateral summits had a very limited impact, so that the economic and trading powers have strategically adopted other negotiating arenas. This explains the main outline of the results obtained from the ratification analysis using hypergraphs, with the absence of some of the major economic and commercial powers at the global level, while the countries that participate little in global trade are generally present.

Hypergraph analysis of the ratification dynamics of environmental versus trade agreements highlights the contrast between the two regimes, in particular the identification of the emerging EU community

\footnotetext{
${ }^{142}$ Brazil, South Africa, India, China.

${ }^{143}$ See, for example, the One Planet Summit held in Paris on December 12, 2017.
} 
only in the first case. Is it still a "normative power" in the trade framework under the leadership of the United Nations? The mainstream of the economic policy analysis says that the EU has lost its strength since the 2008 crisis and the Chinese rise, but the assessment of the EU's role is still subject to profound divergences. In this sense, our results show that despite the fact that the UN serves as a bridge between the two regimes, it is much more effective in promoting environmental agreements than regulating global trade. Therefore the $\mathrm{UN}$ is at the same time central to the environment and marginal to trade agendas ${ }^{144}$. However in the future it would be appropriate to extend the analysis undertaken in this work by considering the treaties and agreements ratified in the WTO in relation to the G7 meetings, then G8 and G20 in order to have a second, broader analysis in the sense that it would comply more with the current global (and nevertheless fragmented) governance of commercial and environmental issues (but then without respecting the homogeneity of the sources of the data taken into account) (see also Morin et al., 2018)

Finally, the concept of sustainable development cannot be considered as a structuring principle of international relations, given that the trade regime prevails over that of the environment in practice, as demonstrated in particular by the ongoing negotiations of mega-agreements, the TTP and TTIP, and within ASEAN.

Acknowledgments. Ana Flávia Barros-Platiau wishes to thank the agency CAPES (Programas Estratégicos - DRI, call 43/2013) of the Ministry of Education in Brazil and the CIRCULEX project, founded by ANR (French National Agency for Research). Pierre Mazzega conducts this research as part of the project GEMA «Gouvernance Environnementale: Modélisation et Analyse» founded by CNRS (French National Center for Scientific Research) through the program Défi interdisciplinaire: «InFIniti» Interfaces Interdisciplinaires Numérique et Théorique.

\section{REFERENCES}

Abbot K, Snidal D (2000) Hard and soft law in international governance. International Organization 54(3):421-456

Barnett M, Finnemore M (2004) Rules for the Word. International organizations in global politics. Cornell Univ. Press, Ithaca NY

Barnett M, Finnemore M (2007) Political approaches. In: T. Weiss and S. Daws (eds) The Oxford Handbook on the United Nations, Oxford Univ. Press, Oxford

Battistella D (2009) Théories des Relations Internationales. Presses de Sciences Po, Paris

Biermann F, Abbott K, Andresen S, Bäckstrand K, Bernstein S, Betsill MM, Bulkeley H, Cashore B, Clapp J, Folke C, Gupta A, Gupta J, Haas PM, Jordan A, Kanie N, Kluvánková-Oravská T, Lebel L, Liverman D, Meadowcroft J, Mitchell RB, Newell P, Oberthür S, Olsson L, Pattberg P, Sánchez-Rodríguez R, Schroeder H, Underdal A, Vieira SC, Vogel C, Young OR, Brock A, Zondervan R (2012) Science and government. Navigating the anthropocene: improving Earth system governance. Science 335(6074):1306-7. doi: 10.1126/science.1217255

Boulet R, Barros-Platiau AF, Mazzega P (2016) 35 years of Multilateral Environmental Agreements ratification: a network analysis. Artificial Intelligence and Law 24:133-148. DOI 10.1007/s10506016-9180-7

\footnotetext{
${ }^{144}$ Certainly, the creation of the World Trade Organization (WTO) outside the UN framework is a central factor in understanding the governance of global trade. But the ratifications analyzed are those of the UN for the sake of comparing two initiatives within the same system, the UN.
} 
Brundtland GH (1987) Notre avenir à tous. Rapport de la Commission des Nations Unies sur l'Environnement et le Développement, New York. Available via http://www.diplomatie.gouv.fr/sites/odyssee-developpement-durable/files/5/rapport_brundtland.pdf Accessed 9 Feb 2018.

Burton J (1972) World society. Cambridge University Press, Cambridge

Chang N (2016) Strategies of Ratification and the Paris Agreement. Available via https://nickdotchan.wordpress.com/2016/04/05/strategies-of-ratification-and-the-paris-agreement/ Accessed 9 Feb 2018

Crutzen PJ, Steffen W (2003) How Long Have We Been in the Anthropocene Era? Climatic Change 61(3):251-257. https://doi.org/10.1023/B:CLIM.0000004708.74871.62

de Cravalho FV (2012) The Brazilian position on forests and climate change from 1997 to 2012: from veto to proposition. Rev. Bras. Polít. Int. 55:144-169. Available via http://www.scielo.br/pdf/rbpi/v55nspe/09.pdf Accessed 9 Feb 2018

Devin G, Smouts MC (2012) Les organisations internationales. Armand Colin, Paris

Falkner R (2015) International negotiations: towards mini-lateralism. Nature Climate Change 5:805806. doi:10.1038/nclimate2767

Gallo G, Longo G, Pallotino S, Nguyen S (1993) Directed hypergraphs and applications. Discrete Applied Mathematics 42:177-201

Hearn A (2016) The changing currents of transpacific integration china, the TPP, and beyond. Lynne Rienner Publishers, Bouder CO

Hoge JF (2004) A global power shift in the making. Foreign Affairs. Available via https://www.foreignaffairs.com/articles/united-states/2004-07-01/global-power-shift-making Accessed 9 Feb 2018

IISD / UNEP (2005). Environment and trade: a handbook, 2nd edition. The United Nations Environment Programme Division of Technology, Industry and Economics and Trade Branch and the International Institute for Sustainable Development, Geneva. Available via www.iisd.org/pdf/2005/envirotrade_handbook_2005.pdf Accessed 9 Feb 2018

Karns M, Mingst K, Stiles K (2015) International organizations. The politics and processes of global governance. Lynne Rienner Publishers, Boulder CO

Keohane R, Nye J (1977) Power and interdependence: world politics in transition. TBS The Book Service Ltd, Colchester

Keohane R, Victor D (2010) The regime complex for climate change. Harvard Project on climate agreements, Belfer Henter, Harvard. Available via https://www.belfercenter.org/publication/regime-complex-climate-change Accessed 9 Feb 2018

Krasner S (1983) International Regimes. Cornell University Press, Ithaca NY

Laïdi Z(2006) La norme sans la force. L'énigme de la puissance européenne. Presses de la Fondation Nationale des Sciences Politiques, Paris

Lantis JS (2009) The life and death of international treaties. Oxford Univ. Press, Oxford

Le Prestre P (2011) Vingt ans après : Rio et l'avant-goût de l'avenir. Presses de l'Université de Laval, Laval

Meadows DH, Meadows DL, Randers J, Behrens WW III (1972) The limits to growth: a report for the Club of Rome's project on the predicament of mankind. Universe Books, New York. Available via https://archive.org/details/TheLimitsToGrowth Accessed 9 Feb 2018

Mearsheimer J (2001) The tragedy of great power politics. W.W. Norton \& Company, New York

Moravcsik A (1997) Taking preferences seriously. A liberal theory of International Relations. International Organization 51 (4):513-553. https://doi.org/10.1162/002081897550447

Morin JF, Dür, Lechner L (2018) Mapping the Trade and Environment Nexus: Insights from a New Data Set. Global Env. Politics. https://doi.org/10.1162/GLEP_a_00447 
Nakicenovic N, Rockström J, Gaffney O, Zimm C (2016) Global commons in the Anthropocene: world development on a stable and resilient planet. Working Paper 16-019. Intern. Inst. for Applied Systems Analysis, Laxenburg. Available via http://pure.iiasa.ac.at/14003/ Accessed 9 Feb 2018

OCDE (1982) Interdépendance économique et écologique: un rapport sur quelques problèmes posés par l'environnement et les ressources. Organisation de Coopération et de Développement Economiques, Paris

Ohmae K (1985) La Triade. Emergence d'une stratégie mondiale de l'entreprise. Flammarion, Paris

Ostrom E, Dietz T, Dolsak N, Stern PC, Stonich S, Weber E (eds) (2002) The Drama of the Commons. Natl. Acad. Press, Washington DC

Porter G, Brown J (1991) Global environmental politics. Westview Press, Boulder CO

Rosenau J (1990) Turbulence in world politics: a theory of change and continuity. Princeton University Press, Princeton

Shelton D, Kiss A (2007) Guide to international environmental law. Martinus Nijhoff Publ., Leiden

Strange S (1998) States and markets, 2nd ed. Bloomsbury Academic, London

UNEP (2017a) Towards a pollution-free planet. United Nations Environment Assembly of the United Nations Environment Programme, Nairobi. Available via http://www.unep.org/assembly/backgroundreport Accessed 9 Feb 2018

UNEP (2017b) Frontiers 2017. Emerging issues of environmental concern. United Nations Environment Programme, Nairobi. Available via https://www.unenvironment.org/. Accessed 9 Feb 2018

Viola E, Franchini M (2018) Brazil and climate change. Beyond the Amazon. Routledge, Abingdon von Luxburg U (2007) A tutorial on spectral clustering. Stat. Comput. 17(4):395-416 